\title{
Sciendo
}

\section{Livros Novos}

Publicados em 1997

Desidério Murcho

Universidade de Lisboa

Disputatio No. 3

November 1997

DOI: $10.2478 /$ disp-1997-0012

ISSN: 0873-626X

(C) 1997 Murcho. Creative Commons Attribution-NonCommercial-NoDerivs 3.0 License 


\section{LIVROS NOVOS}

Publicados em 1997

\section{GERAL, REFERÊNCIA E INTRODUÇÃO}

Blackburn, Simon, Dicionário de Filosofia. Lisboa: Gradiva. 488 pp.

Bostock, David, Intermediate Logic. Oxford UP. ISBN: 0198751419

Clarke, D. S., Philosophy's Second Revolution: Early and Recent Analytic Philosophy. Library Press (Open Court). ISBN: 0812693485

Clément, Élisabeth, Demonque, Chantal, Hansen-Løve, Kahn, Pierre, Dicionário Prático de Filosofia. Lisboa: Terramar. 407 pp.

Copi, Irving M. and Carl Cohen, Introduction to Logic. Prentice Hall. ISBN: 0132425874

Deutsch, Eliot and Ron Bontekoe, eds., A Companion to World Philosophies. Oxford: Blackwell. 608 pp. $£ 65$

Elgin, Catherine Z., Between the Absolute and the Arbitrary. Ithaca, NY: Cornell UP. 205 pp. £12.50

Glock, Hans-Johann, The Rise of Analytic Philosophy. Oxford: Blackwell. 95 pp. £10.99

Gould, James A. Classic Philosophical Questions. Prentice Hall. ISBN: 0023454814

Groarke, Leo, Christopher Tindale and Linda Fisher, Good Reasoning Matters: A constructive approach to critical thinking. (2nd edition) Oxford UP. 362 pp. $£ 14.50$

Hale, Bob and Crispin Wright, eds., A Companion to Philosophy of Language. Oxford: Blackwell. ISBN: 0631167579

Miller, L., Questions That Matter: An Invitation to Philosophy. McGraw-Hill. ISBN: 0070422648. (2nd Edition)

Nagel, Thomas, The Last Word. Oxford UP. 147 pp. £16.99

Norris, Christopher, Against Relativism: Philosophy of Science, Deconstruction, and Critical Theory. Blackwell Pub. ISBN: 0631198652

Russell, Bertrand, Religion and Science. Oxford UP. ISBN 0195115511.

\section{Disputatio 3, Novembro 1997}


Scheffler, Israel, Symbolic Worlds. Art, science, language, ritual. Cambridge UP. 210 pp. $£ 35$

Trusted, Jennifer, An Introduction to the Philosophy of Knowledge (2nd edition) Macmillan. 271 pp. $£ 7.99$

Waller, Bruce N. Critical Thinking: Consider the Verdict. Prentice Hall. ISBN: 0137443684

Wilkin, Peter, Noam Chomsky: On Power, Knowledge and Human Nature. St Martin's Press. ISBN: 0312174772

Wolff, Robert Paul, About Philosophy. Prentice Hall. ISBN: 0137442513

Zeyl, Donald T., Devereux, Daniel, and Mitsis, Phillip. Encyclopedia of Classical Philosophy. Greenwood Publishing Group. ISBN: 03132877 59

\section{METAFÍSICA}

Armstrong, D.M., A World of States of Affairs. Cambridge UP. 285 pp. $£ 14.95$

Devitt, Michael, Realism and Truth. (2nd edition) Princeton UP. $371 \mathrm{pp}$. $£ 15.99$

Ehring, Douglas, Causation and Persistence: A theory of causation. Oxford UP. 191 pp. $£ 27.50$

Elgin, Catherine Z., Between the Absolute and the Arbitrary. Ithaca, NY: Cornell UP. 205 pp. £12.50

Flanagan, Owen, Self Expressions: Mind, morals and the meaning of life. Oxford UP. 222 pp. $£ 17.99$

Ghiselin, Michael T., Metaphysics and the Origin of Species. State University of New York Press. ISBN: 0791434680

Hermann, Luc, Concepts of Realism. Woodbridge: Boydel and Brewer. 246 pp. $£ 40$

Mellor, D.H. and Alex Oliver, eds., Properties. Oxford UP. 276 pp. $£ 12.99$

Salmon, Wesley C., Causality and Explanation. Oxford Univ Pr. ISBN: 0195108647

\section{TEORIA DO CONHECIMENTO}

Floridi, Luciano, Scepticism and the Foundation of Epistemology: A study in the metalogical fallacies. Leiden: Brill. 368 pp. 
Salmon, Wesley C., Causality and Explanation. Oxford Univ Pr. ISBN: 0195108647

Sayre, Kenneth M., Belief and Knowledge: Mapping the Cognitive Landscape. Rowman and Littlefield Publishers Inc. ISBN: 0847684733

Sinnott-Armstrong, Walter and Mark Timmons, Moral Knowledge: New readings in moral epistemology. Oxford UP. 342 pp. £17.50

Trusted, Jennifer, An Introduction to the Philosophy of Knowledge (2nd edition) Macmillan. 271 pp. £7.99

\section{FILOSOFIA DA CIÊNCIA}

Armstrong, D.M., A World of States of Affairs. Cambridge UP. 285 pp. $£ 14.95$

Earman, John and John D. Norton, The Cosmos of Science: Essays of Exploration. Univ of Pittsburgh Press. ISBN: 0822939304

Ehring, Douglas, Causation and Persistence: A theory of causation. Oxford UP. 191 pp. $£ 27.50$

Ghiselin, Michael T., Metaphysics and the Origin of Species. State University of New York Press. ISBN: 0791434680

Hess, David J., Science Studies: An Advanced Introduction. New York University Press. ISBN: 0814735649

Norris, Christopher, Against Relativism: Philosophy of Science, Deconstruction, and Critical Theory. Blackwell Pub. ISBN: 0631198652

Price, Huw, Time's Arrow and Archimedes' Point: New Directions for the Physics of Time. Oxford Univ Pr. ISBN: 0195117980

Russell, Bertrand, Religion and Science. Oxford UP. ISBN 0195115511.

Salmon, Wesley C., Causality and Explanation. Oxford Univ Pr. ISBN: 0195108647

Wassermann, Gerhard, From Occam's Razor to the Rods of Consciousness: 20 Essays on Philosophy, Philosophy of Science and Philosophy of Mind. Avebury. ISBN: 1859722857

\section{FILOSOFIA DA LINGUAGEM, MENTE E COGNIÇÃO}

Baars, Bernard J., In the Theater of Consciousness: The workplace of the mind. Oxford UP. 193 pp. $£ 18.50$

Beaney, Michael, ed., The Frege Reader. Oxford: Blackwell. 432 pp. 115.99 
Elgin, Catherine Z., Between the Absolute and the Arbitrary. Ithaca, NY: Cornell UP. 205 pp. $£ 12.50$

Flanagan, Owen, Self Expressions: Mind, morals and the meaning of life. Oxford UP. 222 pp. $£ 17.99$

Guttenplan, Samuel, The Languages of Logic. (Second edition) Oxford: Blackwell. 448 pp. $£ 15.99$

Hacking, Ian, Rewriting the Soul. Multiple personality and the sciences of memory. Princeton UP. 336 pp. $£ 19.95$

Hale, Bob and Crispin Wright, eds., A Companion to Philosophy of Language. Oxford: Blackwell. ISBN: 0631167579

Keefe, Rosanna, Peter Smith, Vagueness: A Reader. MIT Press. ISBN: 0262112256

Kunne, Wolfgang, Albert Newen, and Martin Anduschus. Direct Reference, Indexicality and Propositional Attitudes. Cambridge UP (CSLI Lecture Notes). ISBN: 1575860716

Lee, Christina, Alternatives to Cognition: A New Look at Explaining Human Social Behavior. Lawrence Erlbaum. ISBN: 0805826548

Martinich, A.P., ed., The Philosophy of Language. (3rd edition) Oxford UP. 577 pp. $£ 19.95$

McGinn, Colin, Minds and Bodies: Philosophers and Their Ideas. Oxford UP. ISBN: 0195113551

Miller, Alex, Philosophy of Language. McGill-Queen's University Press. ISBN: 077351709X

Moltmann, Friederike, Parts and Wholes in Semantics. Oxford UP. ISBN: 019509574X

Sayre, Kenneth M., Belief and Knowledge: Mapping the Cognitive Landscape. Rowman and Littlefield Publishers Inc. ISBN: 0847684733

Schurz, Gerhard, The Is-Ought Problem: An Investigation in Philosophical Logic. Kluwer. ISBN: 0792344103

Searle, John R., Daniel Clement Dennett, David John Chalmers, The Mystery of Consciousness. New York Review of Books. ISBN: 0940322064

Seligman, Adam B., The Problem of Trust. Princeton University Press. ISBN: 0691012423

Steward, Helen, The Ontology of Mind: Events, Processes, and States. Oxford UP. ISBN: 0198240988

Stich, Stephen P., Deconstructing the Mind. Oxford UP. 222 pp. $£ 18.99$ 
Walton, Douglas N., Appeal to Pity: Argumentum Ad Misericordiam. State Univiversity of New York Press. ISBN: 0791434613

Wassermann, Gerhard, From Occam's Razor to the Rods of Consciousness: 20 Essays on Philosophy, Philosophy of Science and Philosophy of Mind. Avebury. ISBN: 1859722857

Wilson, Robert A., Cartesian Psychology and Physical Minds: Individualism and the Science of Mind. Cambridge Univ Pr. ISBN: 052159734X

Woods, Michael and David Wiggins, Conditionals. Oxford UP. ISBN: 0198751265

\section{LÓGICA E FILOSOFIA DA MATEMÁTICA}

Anglin, W. S., The Philosophy of Mathematics: The Invisible Art. Edwin Mellen Press. ISBN: 0773487069

Bostock, David, Intermediate Logic. Oxford UP. ISBN: 0198751419

Bunch, Bryan H., Mathematical Fallacies and Paradoxes. Dover Publications. ISBN: 0486296644

Copi, Irving M. and Carl Cohen, Introduction to Logic. Prentice Hall. ISBN: 0132425874

Hage, J. C. Reasoning With Rules: An Essay on Legal Reasoning and Its Underlying Logic. Kluwer. ISBN: 0792343255

Prakken, Henry, Giovanni Sartor, Logical Models of Legal Argumentation. Kluwer. ISBN: 0792344138

Schurz, Gerhard, The Is-Ought Problem: An Investigation in Philosophical Logic. Kluwer. ISBN: 0792344103

\section{TEORIA DA DECISÃO}

Bichieri, Cristina, Richard Jeffrey and Brian Skyrms, The Dynamics of Norms. Cambridge UP. 234 pp. $£ 40$

Schick, Frederic. Making Choices: A Recasting of Decision Theory. Cambridge U. P. ISBN: 0521588405 


\section{ÉTICA E FILOSOFIA POLÍTICA E DO DIREITO}

Beckwith, Francis J. and Todd Edwin Jones, Affirmative Action: Social Justice or Reverse Discrimination. Prometheus Books. ISBN: 1573921572

Bedan, Hugo Adam, Making Mortal Choices: 3 exercises in moral casuistry. Oxford UP. 123 pp. $£ 12.95$

Benn, Piers, Ethics. McGill-Queen's University Press. ISBN: 0773517014

Bichieri, Cristina, Richard Jeffrey and Brian Skyrms, The Dynamics of Norms. Cambridge UP. 234 pp. $£ 40$

Clark, Stephen R. L., Animals and Their Moral Standing. Routledge: London. $£ 12.99$

Cummiskey, David, Kantian Consequentialism. Oxford UP. 192 pp. $£ 25$

Eflstrom, Gerard, New Challenges for Political Philosophy. Macmillan. 211 pp. $£ 40$

Feldman, Fred, Utilitarianism, Hedonism and Desert: Essays in Moral Philosophy. Cambridge Univ Pr. ISBN: 0521598427

Flanagan, Owen, Self Expressions: Mind, morals and the meaning of life. Oxford UP. 222 pp. $£ 17.99$

Gray, John, Isaiah Berlin. Princeton University Press. ISBN: 069104824X

Griffin, Stephen M., Robert C. L. Moffat, Radical Critiques of the Law. University Press of Kansas. ISBN: 070060846X

Hage, J. C. Reasoning With Rules: An Essay on Legal Reasoning and Its Underlying Logic. Kluwer. ISBN: 0792343255

Kamm, F.M., Morality, Mortality. Vol. 2: Rigths, duties, and status. Oxford UP. 389 pp. $£ 40$

Kramer, Matthew H., John Locke and the Origins of Private Property: Philosophical Explorations of Individualism, Community, and Equality. Cambridge Univ Press. ISBN: 0521584124

Machan, Tibor R., A Primer on Ethics. University of Oklahoma Press. ISBN: 0806129468

Magill, Kevin, Freedom and Experience: Self-determination without illusions. Macmillan. 207 pp. $£ 40$

Mason, H.E., ed., Moral Dilemmas and Moral Theory. Oxford UP. 246 pp. $£ 32.50$

McGinn, Colin, Ethics, Evil and Fiction. Oxford UP. ISBN: 0198237162 
Mele, Alfred R., Autonomous Agents. From self-control to autonomy. Oxford UP. 271 pp. $£ 37.50$

Nagel, Thomas, The Last Word. Oxford UP. 147 pp. £16.99

Nathanson, Stephen, Economic Justice. Prentice Hall. ISBN: 0137418442

Prakken, Henry, Giovanni Sartor, Logical Models of Legal Argumentation. Kluwer. ISBN: 0792344138

Rachels, James, Can Ethics Provide Answers? Lanham, Maryland: Rowman \& Littlefield. 240 pp. £15.95

Rachels, James, Created from Animals: The Moral Implications of Darwinism. Oxford UP. ISBN: 0192861298

Ramsay, Hayden, Beyond Virtue: Integrity and Morality. St Martins Pr. ISBN: 0312174853

Ridley, Matt, The Origin of Virtue. Viking Press. ISBN: 0670863572

Schurz, Gerhard, The Is-Ought Problem: An Investigation in Philosophical Logic. Kluwer. ISBN: 0792344103

Seligman, Adam B., The Problem of Trust. Princeton University Press. ISBN: 0691012423

Sharp, Clifford, The Origin of Human Values. Penguin. 186 pp.

Sher, George, Beyond Neutrality. Perfectionism and politics. Cambridge UP. 259 pp. $£ 14.95$

Sinnott-Armstrong, Walter and Mark Timmons, Moral Knowledge: New readings in moral epistemology. Oxford UP. 342 pp. $£ 17.50$

Statman, Daniel, Virtue Ethics: A Critical Reader. Georgetown University Press. ISBN: 0878402217

Walters, James W., What is a Pearson: An ethical exploration. Champaign: Illinois UP. 187 pp. US\$23.95

\section{ESTÉTICA E FILOSOFIA DA ARTE}

Cooper, David E., ed., Aesthetics: The classic readings. Oxford: Blackwell. 288 pp. $£ 12.99$

Dickie, George, Introduction to Aesthetics: An analytic approach. Oxford UP. 189 pp. £16.50

Kivy, Peter, Philosophies of Arts: An Essay in Differences. Cambridge UP. ISBN: 052159829X

MacOnie, Robin, The Science of Music. Clarendon Press. ISBN: 0198166486 


\section{FILOSOFIA DA RELIGIÃO}

Peterson, Michael, et. al, Philosophy of Religion: Selected readings. Oxford UP. 578 pp. $£ 15.99$

Phillips, D.Z., Mario Von Der Ruhr, and Rush Rhees, Rush Rhees on Religion and Philosophy. Cambridge UP. ISBN: 0521564107

Stewart, David, Exploring the Philosophy of Religion. Prentice Hall. ISBN: 0137578326

\section{HISTÓRIA DA FILOSOFIA}

Ackrill, J.L., Essays on Plato and Aristotle. Oxford: Clarendon. 229 pp. $£ 32.50$

Barnes,Jonathan, Logic and the Imperial Stoa. E. J. Brill. ISBN: 90041082 89

Beaney, Michael, ed., The Frege Reader. Oxford: Blackwell. 432 pp. $£ 15.99$

Clarke, D. S., Philosophy's Second Revolution: Early and Recent Analytic Philosophy. Library Press (Open Court). ISBN: 0812693485

Cooper, David E., ed., Aesthetics: The classic readings. Oxford: Blackwell. 288 pp. $£ 12.99$

Cummiskey, David, Kantian Consequentialism. Oxford UP. 192 pp. $£ 25$

Deutsch, Eliot and Ron Bontekoe, eds., A Companion to World Philosophies. Oxford: Blackwell. 608 pp. $£ 65$

Garrett, Don, Cognition and Commitment in Hume's Philosophy. Oxford UP. 270 pp. $£ 40$

Schoedinger, Andrew B., Readings in Medieval Philosophy. Oxford UP. 853 pp. $£ 22.50$

Solomon, Robert C. and Kathleen M. Higgins, A Short History of Philosophy. Oxford UP. 329 pp. £9.99

Spellman, W. M., John Locke. St Martins Press. ISBN: 0312165110

Wilkin, Peter, Noam Chomsky: On Power, Knowledge, and Human Nature. St Martin's Press. ISBN: 0312174772

(Compilação de Desidério Murcho) 